Review

\title{
PHYTOEXTRACTION: A REVIEW ON ENHANCED METAL AVAILABILITY AND PLANT ACCUMULATION
}

\author{
Clístenes Williams Araújo do Nascimento ${ }^{1 *}$; Baoshan Xing ${ }^{2}$ \\ ${ }^{l}$ UFRPE - Depto. de Agronomia, Rua Dom Manoel de Medeiros s/ $n^{\circ}$ - Dois Irmãos, 52171-900 - Recife, PE - \\ Brasil. \\ ${ }^{2}$ University of Massachusetts, Department of Plant, Soil, \& Insect Sciences, Stockbridge Hall, Amherst, MA, \\ 01003, USA. \\ *Corresponding author <cwanascimento@yahoo.com $>$
}

\begin{abstract}
Phytoextraction has emerged as a novel approach to clean up metal-polluted soils in which plants are used to transfer toxic metals from soils to shoots. This review provides a synthesis of current knowledge on phytoextraction of metals from soils and their accumulation in plants. The objective is to integrate soil-related (root exudates and chemical amendments) and biological advances to suggest research needs and future directions. As far as can be deduced from the literature, it will be some time before phytoextraction may be established as a commercial technology. For chemically-assisted phytoextraction, research has not shown easily biodegradable compounds to overcome the risks associated with the use of EDTA for poorly available metals in soils. On the other hand, significant progress has been made on the physiological and molecular aspects regarding tolerance and phytoaccumulation of metals in plants. A multidisciplinary approach is warranted to make phytoextraction a feasible commercial technology to remediate metal-polluted soils.
\end{abstract}

Key words: EDTA, phytoremediation, heavy metals, organic acids

\section{FITOEXTRAÇÃO: UMA REVISÃO SOBRE DISPONIBILIDADE INDUZIDA E ACUMULAÇÃO DE METAIS EM PLANTAS}

\begin{abstract}
RESUMO: A fitoextração é uma tecnologia emergente para despoluição de solos contaminados por metais pesados que usa plantas para transferir metais do solo para a parte aérea, a qual pode ser removida da área poluída. Esta revisão apresenta uma síntese do atual conhecimento sobre fitoextração de metais pesados do solo e sua acumulação em plantas. O objetivo é integrar em uma mesma discussão os avanços relacionados à química do solo (exsudação radicular e adição de agentes quelantes para aumentar a absorção) e à biologia (tolerância a metais e melhoramento genético) visando sugerir futuras pesquisas na área. Embora promissor, o atual estado de desenvolvimento da fitoextração ainda não permite estabelecê-la como uma tecnologia comercial. A pesquisa ainda não encontrou agentes quelantes facilmente biodegradáveis que possam substituir o EDTA na solubilização de metais pouco disponíveis em solos. Entretanto, significativos progressos têm sido feitos no entendimento dos mecanismos fisiológicos e moleculares de tolerância e acumulação de metais em plantas. Uma abordagem multidisciplinar dos vários aspectos que envolvem a fitoextração poderá tornar essa tecnologia econômica e ambientalmente viável a médio prazo.

Palavras-chave: EDTA, fitorremediação, metais pesados, ácidos orgânicos
\end{abstract}

\section{INTRODUCTION}

Excessive metal concentration in soils pose significant hazard to human, animal and plant health, and to the environment in general. Contamination of soils with toxic metals has often resulted from human activities, especially those related to mining, industrial emissions, disposal or leakage of industrial wastes, application of sewage sludge to agricultural soils, manure, fertilizer and pesticide use. Due to the potential toxicity and high persistence of metals, soils polluted with these elements are an environmental problem that requires an effective and affordable solution.

Although a number of techniques have been developed to remove metals from contaminated soils, many sites remain contaminated because economic and environmental costs to clean up those sites with the available technologies are too high. According to Ensley (2000), the estimated expenses incurred in the remediation of a site contaminated with $\mathrm{Pb}$ using the conventional excavation-landfill approach most commonly practiced in the United States are approximately 
$\$ 150-\$ 350 t^{-1}$. Taking into account such a high demand of economic resources, methods of environmental restoration of metal-polluted soils using a plant-based technology have attracted increasing interest in the last two decades. In this context, phytoremediation has been developed as a cost effective and environmentally friendly remediation method of contaminated soils. Remediation of contaminated soils using plants may cost in the order of US\$20-80 $\mathrm{t}^{-1}$ (Ensley, 2000) or US\$ $0.25 \mathrm{M} \mathrm{ha}^{-1}$ (Cunningham \& Berti, 2000), which makes it an economically attractive approach to decontaminate soils polluted by heavy metals. Phytoremediation for metal-contaminated soils represents a market opportunity of approximately US\$1 billion per year (Glass, 2000) in the USA alone; the U.S. phytoremediation market currently comprises only $0.5 \%$ of the total remediation market, equivalent to circa US\$ 100-150 million per year (Pilon-Smits, 2005). Thus, there is a large repressed demand for such technology. Because of its relatively low costs, phytoremediation poses a viable approach to cleaning up soils in developing countries as well, where funds available for environmental restoration are scarce.

Technologies for metal phytoremediation include: 1) phytoextraction - the use of plants to remove metals from soils and to transport and concentrate them in above-ground biomass; 2) phytostabilization - the use of plants to minimize metal mobility in contaminated soil through accumulation by roots or precipitation within the rhizosphere; and 3) phytovolatilization - the use of plants to turn volatile chemical species of soil metals (Chaney et al., 1997; Garbisu \& Alkorta, 2001; McGrath et al., 2002; Lasat, 2002; Ernst, 2005). Phytoextraction seems to be the most promising technique and has received increasing attention from researchers since it was proposed by Chaney (1983) as a technology for reclaiming metal polluted soils.

Phytoextraction of metal-contaminated soil relies on the use of plants to extract and translocate metals to their harvestable parts (Figure 1). The aim of phytoextraction is reducing the concentration of metals in contaminated soils to regulatory levels within a reasonable time frame. This extraction process depends on the ability of selected plants to grow and accumulate metals under the specific climatic and soil conditions of the site being remediated. Two approaches have currently been used to reach this goal: the use of plants with exceptional, natural metal-accumulating capacity, the so-called hyperaccumulators, and the utilization of high-biomass crop plants, such as corn, barley, peas, oats, rice, and Indian mustard with a chemically enhanced method of phytoextraction (Huang et al., 1997; Salt et al., 1998; Lombi et al., 2001; Chen

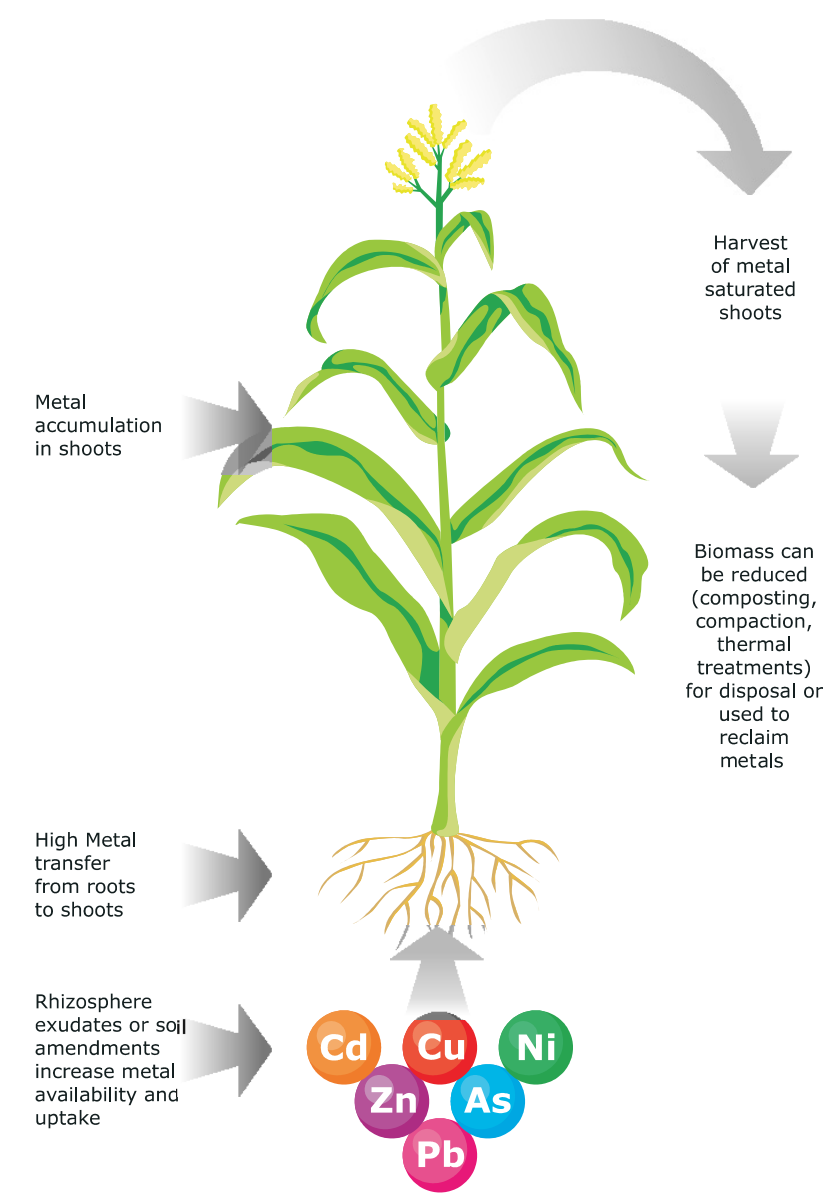

Figure 1 - Schematic representation of the processes involved in phytoextraction of metals from soils.

et al., 2004). The main characteristics of these two phytoextraction systems are summarized in Table 1.

The current knowledge on how root exudates, as well as organic acids and synthetic chelator amendments, might hasten both the phytoextraction of metals from soil and their translocation to shoots is explored ahead. As the ability of plants to accumulate metals is somewhat dependent on their capacity to tolerate high levels of metals in tissues, some mechanisms involved in metal accumulation by plants such as compartmentation in the vacuole and chelation in the cytoplasm are also examined.

\section{Role of root exudates in metal phytoextraction}

Taking into account the significant advances in the knowledge of root biology during the last decade (Waisel et al., 1996; Walker et al., 2003), roots can no longer be considered a hidden half. However, knowledge on the more complex rhizospheric processes mediated by root exudates has not developed at the same pace as the knowledge on roots biology overall (Bais et al., 2004), and much remains to be investigated regarding phytoextraction systems as well. 
Table 1 - Main characteristics of the two strategies of phytoextraction of metals from soils.

\begin{tabular}{ll}
\hline Chemically assisted phytoextraction & Natural phytoextraction \\
\hline $\begin{array}{l}\text { Plants are normally metal excluders } \\
\text { Fast growing, high biomass plants }\end{array}$ & Plants naturally hyperaccumulate metals \\
$\begin{array}{l}\text { Synthetic chelators and organic acids are used to enhance } \\
\text { metal uptake }\end{array}$ & Natural ability to extract high amount of metals from soils \\
$\begin{array}{l}\text { Chemical amendments increase the metal transfer from roots } \\
\text { to shoots }\end{array}$ & Efficient translocation of metals from roots to shoots \\
$\begin{array}{ll}\text { Low tolerance to metals; the increase in absorption leads to } \\
\text { plant death }\end{array}$ & $\begin{array}{l}\text { High tolerance; survival with high concentrations of metals } \\
\text { in tissues }\end{array}$ \\
Risk of leaching of metal chelates to groundwater & No environmental drawback regarding leaching of metals \\
\hline
\end{tabular}

Notwithstanding the fate of exudates in the rhizosphere, and the nature of reactions involved in phytoextraction and transport of metals by plants being not yet fully understood, it is recognized that they contribute significantly to the accumulation of metals in plants. Chemical compounds likely to occur in the rhizosphere are clearly associated with increase of metals uptake from soil and their translocation to shoots (Mench \& Martin, 1991; Salt et al., 1995; Krishnamurti et al., 1997; Lin et al., 2003; Wenzel et al., 2003).

Low molecular-weight organic acids are probably the most important exudates in natural phytoextraction systems. They influence the acquisition of metals by either forming complexes with metal ions or decreasing the $\mathrm{pH}$ around the roots and altering soil characteristics. Despite the fact that metals uptake may be increased due to decreasing $\mathrm{pH}$ (Brown et al., 1994), it is clear that the complexing capacity of organic acids, rather than their capacity to decrease $\mathrm{pH}$, is the main factor related to mobilization of metals in soil and their accumulation in plants (Bernal et al., 1994; McGrath et al., 1997; Gupta et al., 2000; Quartacci et al., 2005). Indirect effects of root exudates on microbial activity, rhizosphere physical properties and root growth dynamics may also influence ion solubility and uptake (Marschner, 1995; Walker et al., 2003). For instance, microorganisms have been shown to mobilize $\mathrm{Zn}$ for hyperaccumulation by Thlaspi caerulescens (Whiting et al., 2001) via dissolution of $\mathrm{Zn}$ from the non-labile phase in soil.

Some plants release specific metal-chelating or reducing compounds into the rhizosphere to aid the absorption of $\mathrm{Fe}$ and $\mathrm{Zn}$ when availability of these micronutrients is low (Marschner, 1995). Other environmental stimuli have also been associated with root exudation of organic acids, including anoxia (Marschner, 1995) and exposure to $\mathrm{Al}$ (Ma, 2000; Piñeros et al., 2002). It is thought that metal accumulators may enhance metal solubility by releasing chelators from the roots. However, only a few reports on the involvement of specific exudates in the uptake and accumulation of potentially toxic metals by plants are known so far. In addition, the exudation rates and chemical composition of exudates of hyperaccumulator species are virtually unknown.

Salt et al. (2000) were unable to identify any high-affinity Ni-chelator compound in the rhizosphere of the Ni hyperaccumulator Thlaspi goesingense. In contrast, they found that $\mathrm{Ni}$-chelators histidine and citrate accumulated in the root exudates of the nonhyperaccumulator Thlaspi arvense exposed to Ni. Such findings led the authors to suggest that the release of these exudates by $T$. arvense may be a strategy to reduce Ni uptake and toxicity, but exudate releasing is not involved in the hyperaccumulation of $\mathrm{Ni}$ by $T$. goesingense. Persans et al. (1999) also established that Ni hyperaccumulation in $T$. goesingense is not determined by the overproduction of histidine in response to Ni. Since at non-toxic Ni concentrations, both plant species translocate $\mathrm{Ni}$ to shoots at equivalent rates (Krämer et al., 1997), the existence of a more efficient translocation mechanism in $T$. goesingense does not seem to explain the capability of this species in accumulating Ni. Krämer et al. (2000) provided evidence that free histidine may be also involved in shuttling $\mathrm{Ni}$ across the cytoplasm into the vacuole in $T$. goesingense, which could be responsible for Ni tolerance and accumulation. Krämer et al. (1996) have already reported a 36 -fold increase in the concentration of free histidine in the xylem exudates of the $\mathrm{Ni}$ hyperaccumulator Alyssum lesbiacum after exposure to $\mathrm{Ni}$, suggesting that histidine could be involved in the transport and storage of $\mathrm{Ni}$ in such species. Kerkeb \& Krämer (2003) recently provided further evidence that histidine enhances the release of $\mathrm{Ni}$ from roots into the xylem, not only in A. lesbiacum but also in the nonhyperaccumulator B. juncea. Salt et al. (2000) identified $\mathrm{Zn}$-histidine complexes in the roots of the $\mathrm{Zn}$ hyperaccumulator Thlaspi caerulescens, but Knight et al. (1997), McGrath et al. (1997) and Zhao et al. (2001) 
did not detect any specific exudate related to accumulation of $\mathrm{Zn}$ by this species.

Not only the role that rhizosphere exudates play in accumulation of $\mathrm{Ni}$ and $\mathrm{Zn}$ is not fully understood, but there is also a lack of information on the role of root exudation in metal phytoextraction for most of the environmentally-relevant metals. As a matter of fact, there is no conclusive evidence so far that hyperaccumulators exude specific chelators in the rhizosphere to enhance metal uptake. Therefore, the release of specific chelators associated with enhanced metal uptake and translocation needs more intensive research. Indeed, increasing root uptake is the first step to successful removal of metals from soils. Insights into the understanding of these processes and the compounds involved are essential to boost phytoextraction technology.

As pointed out by Ryan et al. (2001), the fact that plants can benefit from organic acid exudation in a number of ways has aroused interest of genetic engineering to increase organic acid exudation in crop and pasture species. These authors sustain that large changes in organic acid production can be achieved in yeast and bacteria by inactivating or overexpressing specific genes whose products are involved in organic acid biosynthesis. These studies with microorganisms may be helpful in determining which enzymes could be successfully manipulated to alter organic acids biosynthesis and organic acid exudation in plants.

Of course, such an advance on the knowledge of genetic control of root exudation would be used to hasten the ability of plants in extracting metals from soil. Once specific root exudates related to increasing uptake of metals from soil are identified, plants could be genetically engineered aiming at higher exudation of such natural biodegradable compounds. Genetic manipulation of plant rhizosphere to enhance metal solubility may thus be a good bet, and may not only make phytoremediation more efficient but also overcome environmental constraints associated with chemicallyassisted phytoextraction.

\section{The use of chemical amendments to enhance metal} phytoextraction and accumulation

Metal solubility and availability are both dependent on soil characteristics and are strongly influenced by $\mathrm{pH}$ and the degree of complexation with soluble ligands (Kaschl et al., 2002). Metals exist in soil in various pools: in solution as ionic or organically complexed species; on exchange sites of reactive soil components; complexed with organic matter; occluded in $\mathrm{Fe}, \mathrm{Al}$, and $\mathrm{Mn}$ oxides and hydroxides; entrapped in primary and secondary minerals (Shuman, 1985; Mann \& Ritchie, 1993). Most metals in soils exist in unavailable forms, thus soil conditions have to be altered to elicit phytoextraction since the phenomenon, depends on a relatively abundant source of soluble metal to enable significant metal uptake and translocation to shoots. Metals such as $\mathrm{Pb}$ and $\mathrm{Cr}$ have their extraction rate limited by their inherently low solubility. In such a case, organic compounds can be utilized as amendments to enhance phytoextraction. Such substances can complex and chelate metal ions, therefore modifying the availability of metals in soils.

Ethylenediaminetetraacetate (EDTA) is probably the most studied amendment in phytoremediation research. It has been successfully utilized to enhance phytoextraction of lead and other metals from contaminated soils (Cunninghan \& Ow, 1996; Blaylock et al., 1997; Chen et al., 2004). Huang et al. (1997) showed that EDTA was the most efficient chelator for inducing the hyperaccumulation of $\mathrm{Pb}$ in pea plants shoots (Figure 2), a naturally $\mathrm{Pb}$ excluder. Blaylock et al. (1997) demonstrated that the ability of soil-applied EDTA to increase metal uptake in a multi-contaminated soil is not limited to $\mathrm{Pb}$, since EDTA was also efficient in increasing $\mathrm{Cd}, \mathrm{Cu}, \mathrm{Ni}$, and $\mathrm{Zn}$ concentrations in shoots of $B$. juncea. However, synthetic chelators such as EDTA are barely degradable by microorganisms and can pose a threat to the environment by metal leaching to groundwater (Sun et al., 2001; Wenzel et al., 2003; Madrid et al., 2003; Chen et al., 2004), and adverse effects on soil microbiota (Welper \& Brummer, 1997; Bouwman et al., 2005). We also observed EDTA toxicity and drastic plant growth reduction in Indian mustard grown on a metal multicontaminated soil (Nascimento et al., 2006). Successful phytoextraction depends not only on metal concentration in shoots but also on high biomass production. Thus, maintaining plants capable of accumulating metals as long as pos-

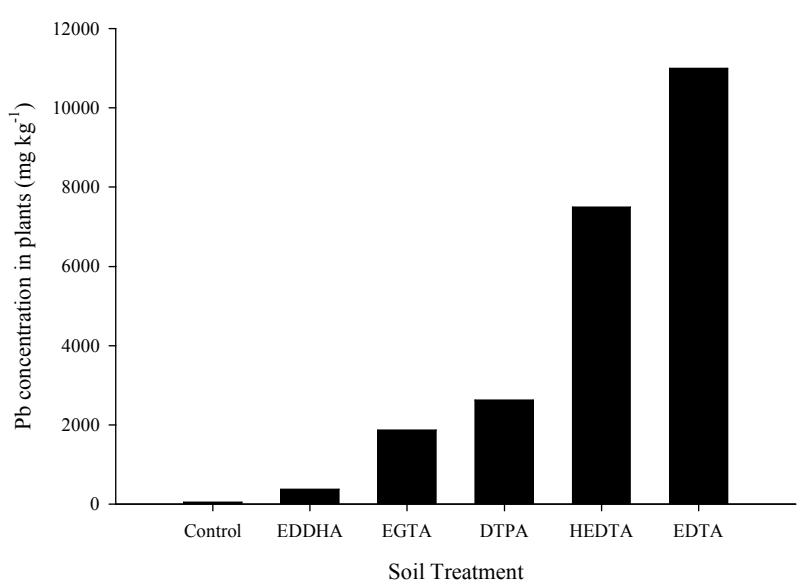

Figure 2 - The effect of five chelators added to a contaminated soil at concentration of $0.5 \mathrm{~g} \mathrm{~kg}^{-1}$ soil on $\mathrm{Pb}$ uptake by pea plants (Data from Huang et al., 1997). 
sible is desirable in phytoextraction. For instance, it has been observed that citrate and gallic acid were as effective as EDTA at enhancing removal of $\mathrm{Cd}, \mathrm{Zn}, \mathrm{Cu}$, and $\mathrm{Ni}$ from soil, as a result of the higher biomass production of plants treated with citrate and gallic acid, in comparison to EDTA-treated plants (Nascimento et al., 2006).

The amount of metals made soluble by synthetic chelators usually exceeds by far the plant's uptake capacity, although attempts should be made to minimize this by applying the chelator at the time of maximum crop biomass (Salt et al., 1998). This high amount of soluble metals implies risks related to groundwater pollution when such chelators are applied under field conditions. Chen et al. (2004) reported high mobility of EDTA-chelated metals in soils columns after water application, equivalent to $158 \mathrm{~mm}$ of rainfall precipitation within 2 days (Table 2). Amounts of $\mathrm{Pb}, \mathrm{Cu}, \mathrm{Zn}$, and $\mathrm{Cd}$ in the leachates increased dozens of times after addition of $5 \mathrm{mmol} \mathrm{kg}^{-1}$. In a lysimeter study under field condition using another synthetic chelator (EDGA), Römkens et al. (2002) observed that dissolved $\mathrm{Cu}$ and $\mathrm{Cd}$ remained mobile in soil and leaching prone. Therefore, even if suitable irrigation strategies are implemented as proposed (Blaylock et al., 1997; Madrid et al., 2003), the potential of metals leaching in synthetic chelator-treated soil is still high during seasons of intense rainfall. In a preliminary study that used 1 week-old seedlings, Li et al. (2005) registered that turning EDTA into a slow-release compound through coating of the EDTA granules with silicates could reduce the risk of metal leaching. More studies with older plants on a field scale are needed to assess the usefulness of this technique for overcoming the leaching risks while maintaining a high metal uptake rate by plants.

Results of Satroutdinov et al. (2000) not only corroborate the persistence of EDTA towards biological degradation but also demonstrate that the most stable metal-EDTA complexes (i.e. chelates of $\mathrm{Cu}^{2+}$, $\mathrm{Co}^{2+}, \mathrm{Zn}^{2+}$, and $\mathrm{Pb}^{2+}$ ) have to dissociate prior utilization by bacteria. As a consequence, metal-EDTA com- plexes may be found in soil pore water up to five months after EDTA application (Lombi et al., 2001). This slow degradation rate and high persistence increase the leaching risk associated with EDTA application in field conditions. Indeed, such effects must be weighed against its use in phytoextraction. Some biodegradable synthetic chelators, such as ethylenediaminedissuccinate (EDDS) and methylglycinediacetate (MGDA), have been evaluated as EDTA alternatives (Groman et al., 2003; Tamura et al., 2005). Although to date these chelators have not been extensively studied, they show promise for environmentally safe phytoextraction, especially for $\mathrm{Pb}$-contaminated soils.

Taking into account the negative side-effects of applied synthetic chelators, the use of root-produced agents which are naturally degradable by microorganisms is preferable. Such an approach sounds better to the public acceptance of phytoextraction technology. Unfortunately, a large body of literature has demonstrated the lower effectiveness of natural organic acids on metals mobilization and subsequent plant uptake as compared to synthetic chelators, especially in the case of $\mathrm{Pb}$ phytoextraction (Salt et al., 1995; Gupta et al., 2000; Lombi et al., 2001; Wu et al., 2003; Kos $\&$ Lestan, 2004). The efficiency of organic acids released by roots to mobilize metals from soil seems to depend upon the rate of biodegradation (Krishnamurti et al., 1997; Renella et al., 2004). The biodegradation process is under control of the soil's microbial community, which is also not fully understood (Ryan et al., 2001), but the process of consumption of organic acids by microorganisms is probably an important process in reducing their effectiveness in complexing metals around the plant roots. As a result, low effectiveness of phytoextraction using natural organic acids has been reported due to rapid mineralization when small doses are applied (Romkens et al., 2002; Meers et al., 2004). On the other hand, higher doses may be toxic to plants (Turgut et al., 2004), resulting in impaired phytoextraction. Thus, it might be necessary to add organic acids several times to maintain an optimal con-

Table 2 - Total amounts of $\mathrm{Pb}, \mathrm{Cu}, \mathrm{Zn}$, and $\mathrm{Cd}$ in leachates after application of $1000 \mathrm{~mL}$ of rainwater in soil columns (adapted from Chen et al., 2004).

\begin{tabular}{lccc}
\hline \multirow{2}{*}{ Metal } & \multirow{2}{*}{ Total content of metals in soil columns } & \multicolumn{2}{c}{ Metals in leachates } \\
\cline { 3 - 4 } & & Without EDTA & With EDTA \\
\hline $\mathrm{Pb}$ & 3280 & 1.58 & 116 \\
$\mathrm{Cu}$ & 860 & 3.19 & 236 \\
$\mathrm{Zn}$ & 1730 & 6.47 & 3.25 \\
$\mathrm{Cd}$ & 15.8 & 0.13 & mg \\
\hline
\end{tabular}


centration of soluble metals during the phytoextraction process. Krishnamurti et al. (1997) observed that Cd release from soils increased initially up to a reaction period of $2 \mathrm{~h}$ and then slowly decreased with time; increasing amounts of $\mathrm{Cd}$ were released from the soils with renewal of organic acids every two hours. These results highlight the importance of the kinetics of metal release from low molecular weight organic acids and their degradation rate. They also point towards research needs that will be essential for optimizing the phytoextraction using these compounds.

For instance, coating natural organic acids to maintain a stead concentration of metal-organic acids complexes in soil solution, as done to EDTA by Li et al. (2005), could be an alternative. Apparently fast biodegradation rather than the low organic acid ability to solubilize metals is the main reason for unsuccessful phytoextraction (Krishnamurti et al., 1997; Nascimento et al., 2006). Thus, the slow release of organic acids from coated materials could provide a sustained uptake rate while decreasing the rapid disappearance of metalorganic acid complexes from the soil solution by buffering the solution for chelators.

Despite the relative success observed for metals of low solubility in soils, chemically-enhanced phytoextraction has faced serious limitations when applied to multi-contaminated sites with more bioavailable metals. Metals such as $\mathrm{Cd}, \mathrm{Zn}$, and $\mathrm{Cu}$ may cause severe toxicity to plants even before chelators are added to soil (Sun et al., 2001; Lombi et al., 2001; Marchiol et al., 2004; Wu et al., 2004). Such an inhibition of plant growth limits phytoextraction success. For example, Lombi et al. (2001) suggested that phytoextraction of $\mathrm{Zn}$ and $\mathrm{Cd}$ by T. caerulescens is constrained by $\mathrm{Cu}$ toxicity. Similarly, Ebbs \& Kochian (1997) observed that the removal of $\mathrm{Zn}$ and $\mathrm{Cu}$ from soil solution by Brassica species was reduced in the presence of both metals, as compared to single metal treatments. Thus, the chelator enhancement seems to be plant- and metal-specific, and might be inhibited when multiple metals are present.

Exceptional results of metal phytoextraction have been reported, especially on $\mathrm{Pb}$ accumulation (Huang et al., 1997; Blaylock et al., 1997; Vassil et al., 1998). However, results from soils artificially contaminated with a single metal do not address the "real life" multicontaminated soils. For instance, $70 \%$ of all metal-contaminated Superfund sites in The United States involve two or more metals (Forstner, 1995). The development of plants and processes which can efficiently decontaminate these sites is a great research challenge. This must be a focus in phytoextraction research if phytoremediation technology is to be broadly used in field conditions.
Together with a high extraction rate by roots, the success of phytoextraction depends on substantial increases in the transfer of metals to shoots. Actually, the chemically-induced phytoextraction must be seen as a two-step process in which plants first accumulate metals in their roots, and then translocate them to the shoots more efficiently as a consequence of environmentally-safe chelator addition.

Vassil et al. (1998) found that Indian mustard exposed to $\mathrm{Pb}$ and EDTA in nutrient solution accumulated $11,000 \mathrm{mg} \mathrm{kg}^{-1} \mathrm{~Pb}$ in dry shoot tissue. Blaylock (2000) described two successful field demonstrations of the use of EDTA-assisted phytoextraction of $\mathrm{Pb}$ by Indian mustard. It has also been demonstrated that addition of synthetic chelators increase the translocation not only of $\mathrm{Pb}$ but also of $\mathrm{Cd}, \mathrm{Zn}, \mathrm{Cu}$ and $\mathrm{Ni}$ (Blaylock et al., 1997). However, unsuccessful cases have also been reported. Lombi et al. (2001) concluded that EDTA increased metal mobility in soil and uptake by roots, but did not substantially increase the transfer of metals $(\mathrm{Cd}$, $\mathrm{Zn}, \mathrm{Pb}, \mathrm{Cu}$ ) to corn shoots. They suggested that EDTA was far more efficient in overcoming the diffusion limitation of metals to the root surface than the barrier of root to shoot translocation. Ebbs \& Kochian (1998) showed that EDTA increased the concentration of Zn in shoots of Indian mustard to a lesser degree than the values reported by Blaylock et al. (1997). The contradiction can be attributed to differences in metal solubility in soils. Blaylock et al. (1997) spiked the soil tested with $\mathrm{ZnCO}_{3}$, which may be more easily solubilized by EDTA than Zn present in the aged-contaminated soil used by Ebbs \& Kochian (1998).

The understanding of the physiological mechanisms involved in accumulation of metals in shoots is still incipient. Metals themselves can damage plant membranes (Marschner, 1995), and as a result high concentrations of $\mathrm{Pb}$ (Kumar et al., 1995), and Cd (Salt et al., 1995) alone might induce elevated accumulation of these metals in plants. Salt et al. (1995) demonstrated that Cd toxicity might cause the breakdown of physiological barriers for the accumulation of metals in shoots due to the dramatic effect of toxic concentrations of $\mathrm{Cd}$ in nutrient solution on $\mathrm{Cd}$ concentration in xylem sap.

Vassil et al. (1998) speculated that synthetic chelates can destroy physiological barriers in roots that control the uptake and translocation of metals, for instance, by removal of $\mathrm{Zn}$ and $\mathrm{Ca}$ from the plasma membrane. Regardless the exact mechanism involved, metal-EDTA complexes are absorbed by plants and transported to shoots via the xylem (Epstein et al., 1999; Collins et al., 2001). Sarret et al. (2001) demonstrated that the mechanism of metal accumulation in Phaseolus vulgaris induced by EDTA depends upon 
the nature of the studied metal. Regarding $\mathrm{Zn}$, they did not observe difference between plants grown in $\mathrm{Zn}$ EDTA and $\mathrm{Zn}(\mathrm{SO})_{4}$ solutions. In both cases, $\mathrm{Zn}$ was found predominantly precipitated as $\mathrm{Zn}$ phosphate in roots and leaves. In contrast, cerussite was the major form of $\mathrm{Pb}$ in the absence of EDTA, whereas in the presence of EDTA, part of the $\mathrm{Pb}$ present in the leaves was complexed as Pb-EDTA. Thus, Sarret et al. (2001) concluded that metal-EDTA complexes in soil solution can be totally $(\mathrm{Zn})$ or partially $(\mathrm{Pb})$ dissociated when absorbed by P. vulgaris. Furthermore, as the concentrations of both $\mathrm{Pb}$ and $\mathrm{Zn}$ in the shoots were much higher in plants grown in EDTA solution, the translocation of $\mathrm{Zn}$ from roots to shoots in P. vulgaris does not seem to be dependent on EDTA complexation.

\section{Metal hyperaccumulation and tolerance in plants}

The capacity to hyperaccumulate metals is a relatively rare phenomenon in the plant kingdom, occurring in approximately 400 species of vascular plants total (Reeves \& Baker, 2000), the vast majority of the species discovered so far being Ni hyperaccumulators. Plant species that can accumulate $\mathrm{Cd}, \mathrm{Pb}, \mathrm{Zn}, \mathrm{Co}$ and $\mathrm{Cu}$ are much less numerous (McGrath et al., 2001).

The concept of hyperaccumulation has been extended to a plant growing in its natural habitat in which those metal concentrations have been recorded in the dry matter of any aboveground tissue. This more detailed definition includes plants that accumulate metals in aerial tissues other than leaves, which might be useful to phytoextraction as well, and disqualify any species that hyperaccumulates metals under artificial conditions, such as massive addition of metals to soil or nutrient solution (Reeves \& Baker, 2000). Despite such observation, chemically-assisted uptake and accumulation of metals is useful for phytoremediation purposes and has currently been developed as a phytoextraction technique as previously discussed.

It is worth pointing out here the great ability of the brake fern Pteris vitata in accumulating arsenic (Ma et al., 2001). This species can accumulate up to $95 \%$ of the As taken up from soil in its shoots. Because this enormous translocation, $P$. vitata shoot concentrations of As can reach up to $23,000 \mu \mathrm{g} \mathrm{g}^{-1}$. Tamura et al. (2005) have recently discovered that common buckwheat (Fagopyrum esculentum Moench) can naturally accumulated up to $4,200 \mu \mathrm{g} \mathrm{g}^{-1}$ of $\mathrm{Pb}$ in the shoot. Amending the soil with the biodegradable chelator MGDA resulted in a 5-fold increase in the $\mathrm{Pb}$ shoot concentration. Common buckwheat is the first known $\mathrm{Pb}$ hyperaccumulator species with high biomass productivity. This relevant finding qualifies this species as an excellent candidate for remediating $\mathrm{Pb}$-contaminated soils.
The precise relationship between metal hyperaccumulation and tolerance is still a subject of debate. Some authors have proposed that there is no correlation between these traits (Baker \& Walker, 1990; Baker et al., 1994), while others suggest that hyperaccumulators possess a high degree of tolerance to metals (Reeves \& Brooks, 1983; Chaney et al., 1997). Macnair et al. (2000) compiled a number of studies in which the accumulation of metals by tolerant and non-tolerant clones of species had been compared, and concluded that there is no pattern regarding tolerance and accumulation. Both shoot and root concentrations are equally variable even when only one particular metal is considered. However, at least in some cases, it is clear that increased tolerance leads to greater accumulation of metals. For instance, Cd tolerance appears to be the most important criterion in developing lines of $T$. caerulescens with great phytoextraction potential (Roosens et al., 2003). As a matter of fact, it is plausible to consider that to cope with high concentrations of metals in their tissue, plants must also hypertolerate the metals that they accumulate.

Plants may use two strategies to deal with high metal concentrations adjacent to their roots: 1) exclusion (avoidance) mechanisms by which the uptake and/ or root-to-shoot transport of metals are restricted; and 2) internal tolerance mechanisms that immobilize, compartmentalize or detoxify metals in the symplasm through production of metal binding compounds (Rauser, 1995; Marschner, 1995; Küpper et al., 1999). Given that the goal of phytoextraction is to maximize metal accumulation in plant tissues, mechanisms of internal tolerance are likely to be important.

Internal tolerance to metals is thought to be based on several mechanisms rather than one alone, and the lack of a comprehensive understanding of this complex metal homeostatic network in plants remains a major bottleneck in the development of phytoextraction technologies (Hirschi et al., 2000; Krämer, 2003). Compartmentation in the vacuole and chelation in the cytoplasm are among the most significant mechanisms proposed to be related to metal accumulation by plants.

Metal transport from the cytosol to the vacuole is considered an important mechanism of both metal tolerance and accumulation in plants. For this reason, much work has been dedicated to investigating subcellular localization of metals in hyperaccumulators (Vázquez et al., 1992; 1994; Küpper et al., 1999; 2000; Hirschi et al., 2000; Krämer et al., 2000; Sarret et al., 2002). Krämer et al. (2000) isolated vacuoles from $\mathrm{Ni}$-tolerant $T$. goesingense and Ni-sensitive $T$. arvense aiming directly to address the 
role of vacuolar Ni storage in Ni tolerance. They found that $T$. goesingense accumulated two-fold more $\mathrm{Ni}$ in the vacuole than $T$. arvense (Figure 3). Since protoplast and apoplast Ni contents were similar in both species, vacuolar compartmentalization in $T$. goesingense seems to play a major role in $\mathrm{Ni}$-accumulation and tolerance.

Subcellular compartmentation in the vacuole is also a mechanism of $\mathrm{Zn}$ tolerance used by the $\mathrm{Zn}$ hyperaccumulator T. caerulescens (Vázquez et al., 1994; Küpper et al., 1999) and probably by Arabidopsis halleri (Neumann \& Zur-Nieden, 2001). In the leaves of the latter species, $\mathrm{Zn}$ is predominantly complexed to malate (Sarret et al., 2002). As this acid seems to be the most abundant organic acid in vacuoles of T. caerulescens (Tolra et al., 1996), it is supposed to be related to metal chelation and accumulation in this species as well. However, as pointed out by Sarret et al. (2002), the mere presence of malate, or another organic acid, does not guarantee high metal accumulation rates in shoots. This is rather dependent on both the location of malate (vacuolar or cytoplasmic) and the quantity of metal transmembrane transporters. For instance, Ni hyperaccumulation in $T$. goesingense is achieved by an efficient system that pumps $\mathrm{Ni}$ into the vacuole of shoot cells (Krämer et al., 2000). Such a vacuolar sequestration of $\mathrm{Zn}$ seems to be driven by a member of the cation diffusion facilitator family (TgMTP1), constitutively-expressed in $T$. goesingense. Similar constitutively enhanced expression by cation diffusion facilitators has also been observed for T. caerulescens and A. halleri (Assunção et al., 2001; Becher et al., 2004).

Lasat \& Kochian (2000) proposed a model to explain the higher accumulation of $\mathrm{Zn}$ by $T$. caerulescens compared to T. arvense (Figure 4). According to their model, several altered transport systems account for the $\mathrm{Zn}$ hyperaccumulation in $T$. caerulescens. The first step is the higher capacity for
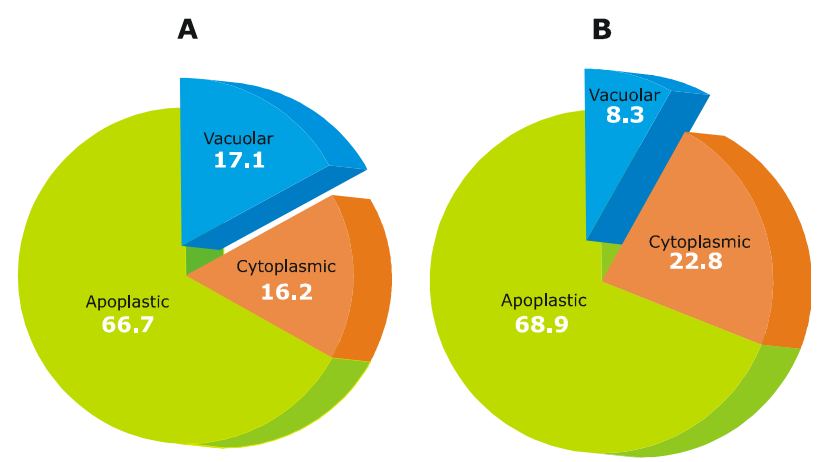

Figure 3 - Subcellular localization of $\mathrm{Ni}$ in leaves of Ni-tolerant $T$. goesingense (A) and $\mathrm{Ni}$-sensitive $T$. arvense (B) as a percentage of total leaf $\mathrm{Ni}$ (Adapted from Krämer et al. 2000)
$\mathrm{Zn}$ influx across the root cell plasma membrane in $T$. caerulescens. Following its entry in the cytoplasm, $\mathrm{Zn}$ is sequestered in the vacuole of $T$. arvense and made unavailable for translocation to the shoot, since the rate of vacuolar $\mathrm{Zn}$ efflux is significantly smaller in $T$. arvense at similar amounts of $\mathrm{Zn}$ accumulated in the root cells of the two Thlaspi species. In $T$. caerulescens, on the other hand, symplasmic $\mathrm{Zn}$ is readily available for loading into the xylem and subsequent long-distance transport to the shoot. As a consequence, T. caerulescens accumulated about five-fold higher concentrations of $\mathrm{Zn}$ in the xylem sap compared to $T$. arvense.

Chelation and sequestration of metals by particular ligands are also mechanisms used by plants to deal with metal stress. The two best-characterized metal-binding ligands in plant cells are the phytochelatins (PCs) and metallothioneins (MTs) (Grill et al., 1988; Cobbett, 2000; Cobbett \& Goldsbrough, 2002). Both ligands are widely distributed in plants and form stable complexes with metals in the cytosol which can be subsequently sequestered into the vacuole (Zenk, 1996; Goldsbrough, 2000). Many physiological and genetic studies indicate that PCs and MTs are critical for metal tolerance and accumulation in plants (Howden \& Cobbett, 1992; Zhu et al., 1999; Schmöger et al., 2000; Inouhe et al., 2000; Hartley-Whitaker et al., 2001; Van Hoof et al., 2001). A comprehensive review of PCs and MTs and their characteristics is found in Cobbett \& Goldsbrough (2002).

Naturally hyperaccumulating plants do not overproduce phytochelatin as part of their mechanism against toxic metals. This appears to be an inducible
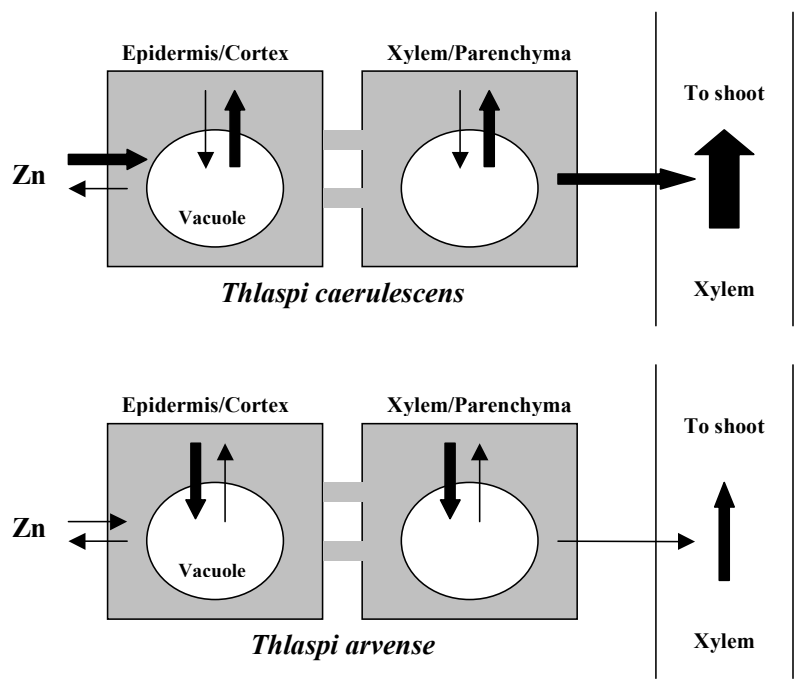

Figure 4 - Model for $\mathrm{Zn}$ transport and compartmentation in root cells of T. caerulescens and $T$. arvense. The thicker the arrow, the higher the $\mathrm{Zn}$ influx or efflux. (Adapted from Lasat \& Kochian, 2000). 
rather than a constitutive mechanism, observed especially in metal non-tolerant plants (Freeman et al., 2005). Instead, hyperaccumulator plants rely on constitutive mechanisms including enhanced vacuolar compartmentation as discussed above. However, overproduction of phytochelatin has played an important role in the attempts to genetically transform high biomass plants into efficient phytoremediators. For example, transgenic seedlings of Brassica juncea overexpressing $\gamma$-glutamylcysteine synthetase $(\gamma$-ECS), had higher concentrations of PCs than wild genotype seedlings (Zhu et al., 1999). As a consequence, the transgenic plants accumulated more $\mathrm{Cd}$ than the wild genotype and possessed shoot Cd concentrations $40 \%$ to $90 \%$ higher. Gisbert et al. (2003) demonstrated that the overexpression of a wheat gene encoding phytochelatin synthase in Nicotiana glauca (shrub tobacco) markedly increased the species tolerance to $\mathrm{Pb}$ and $\mathrm{Cd}$. The transformed plants accumulated twice as more $\mathrm{Pb}$ than the wild type when grown in a mining contaminated soil.

In an innovative and promising approach, Dhankher et al. (2002) combined the $\gamma$ glutamylcysteine synthetase $(\gamma-E C S)$ expression with a leaf-specific arsenate reductase $(\operatorname{ars} C)$, thereby avoiding diminution of the root pool of arsenate (oxidized form) which could move to the leaf. This enabled the transformed Arabidopsis thaliana plants to transport arsenate to aboveground parts where it was reduced to arsenite and sequestered in thiol-peptide complexes, such as PCs and MTs. As a result, As concentrations in shoots were three-fold higher than those of the wild type. This substantial increase in As accumulation, however, is not impressive compared to the high ability of $P$. vitata in concentrating As in the shoots. Additional understanding of the rhizospheric processes involved in As absorption by roots is required to further understanding the increase in As accumulation by transgenic plants. Insights into the effects of root exudates on As, as well as on environmentally important metals $(\mathrm{Pb}, \mathrm{Cd}, \mathrm{Ni}, \mathrm{Zn}, \mathrm{Cu})$ are urgently necessary and will have a dramatic impact on the feasibility of phytoextraction, either by using wild or transgenic plants.

The efficacy of genetically altered plants for phytoremediation has also been successfully tested under actual field conditions (Bañuelos et al., 2005), utilizing three transgenic Indian mustard lines overexpressing genes that encode the enzymes adenosine triphosphate sulfurylase (APS), $\gamma$-glutamylcysteine synthetase $(\gamma-E C S)$, and gluthathione synthetase $(G S)$, respectively. The three transgenic lines accumulated substantially larger amounts of Se in their shoots than the wild type. The APS transgenic line accumulated 4.3-fold more Se in its shoots than wild type, while ECS and GS lines accumulated 2.8-fold and 2.3-fold more Se than wild type, respectively.

The full understanding of the tolerance and accumulation mechanisms of metals and metalloids by plants (Clemens et al., 2002), is a long way ahead but future advances in this field will represent large and essential steps in phytoextraction efforts. No natural hyperaccumulating plant is so far recognized as useful for commercial phytoextraction of metals from multicontaminated soils, but Thlaspi hyperaccumulator species have proved to be an excellent model for studying the mechanisms of metal tolerance and accumulation in plants (Krämer et al., 2000; Freeman et al., 2004; 2005). The greater the knowledge on major genes controlling such traits, the higher the possibility of biotransformation of selected crop species for use in phytoextraction. The outcome of these physiological and genetic studies might ultimately be the fastgrowing, high-biomass, multimetal accumulator plant that researchers have in mind today.

\section{Final Remarks and future research directions}

Important advances have been made in the last few years in understanding the processes involved in phytoextraction of metals from contaminated soils, especially on the processes that contribute to uptake and hyperaccumulation of metals. However, many gaps in both soil chemistry and microbial and plant physiological knowledge must be filled before phytoremediation can become a commercial technology. For example, a better understanding of the interactions taking place in the rhizosphere will be important to the ultimate success of phytoextraction as a technique to clean up soils. Advances in this research field are expected to produce a substantial impact on phytoextraction potential. The identification of specific exudates associated with solubilization of metals in soils could enable alternative ways of manipulating the plant rhizosphere to enhance metal bioavailability.

For chemically-assisted phytoextraction, the dynamics of metal chelates in the rhizosphere need to be examined, either to overcome the risks associated with low degradability of synthetic chelators, or to optimize the use of more biodegradable compounds. Additionally, researchers and policy makers must also look into the chemical pools of metals in soils and identify which ones are the targets for phytoextraction. Although there is a consensus that total concentration does not correlate with bioavailability, most legislation on soil remediation focuses on total concentrations of metals in soils. If this is to be followed, chemical amendments should be reactive enough to extract metals tightly bound to oxides and silicate minerals and 
chelated by organic matter, which represent large metal fractions in contaminated soils, without promoting leaching of metals in the soil profile.

A complete understanding of plant metal tolerance will be essential to develop strategies to genetically enhance the metal accumulation ability of plants. This will have significant implications for phytoremediation. Since most of the known hyperaccumulator species are slow-growing and have small biomass, expressing their metal-accumulating genes in fast-growing, high biomass plants, is a promising approach for developing plants that can be used in phytoextraction technology. Agronomic techniques to successfully grow plants for phytoextraction purposes such as fertilization, timing for chelators application and practices to minimize spread of metals through the food chain, are also awaiting more detailed examination.

\section{ACKNOWLEDGEMENTS}

Dr. Nascimento is grateful to CAPES Foundation, Brazilian Ministry of Education, for a post-doctoral scholarship and to CNPq for a Research Productivity Scholarship. This report was also in part supported by the Massachusetts Agricultural Experiment Station (MS 90 and H8532).

\section{REFERENCES}

ASSUNÇÃO, A.G.L.; MARTINS, P.D.; DE FOLTER, S.; VOOIJS, R.; SCHAT H.; AARTS, M.G.M. Elevated expression of metal transporter genes in three accessions of the metal hyperaccumulator Thlaspi caerulescens. Plant Cell and Environment, v.24, p.217226, 2001.

BAIS, H.P.; PARK, S.W.; WEIR, T.L.; CALLAWAY, R.M.; VIVANCO, J.M. How plants communicate using the underground information superhighway. Trends in Plant Science, v.9, p.26-32, 2004.

BAKER, A.J.M.; WALKER, P.L. Ecophysiology of metal uptake by tolerant plants. In: SHAW, A.J. (Ed.). Heavy metal tolerance in plants: Evolutionary aspects. Boca Raton: CRC Press, 1990. p.155177.

BAKER, A.J.M.; REEVES, R.D.; HAJAR, A.S.M. Heavy metal accumulation and tolerance in British populations of the metallophyte Thlaspi caerulescens J. and C. Presl (Brassicaceae). New Phytologist, v.127, p.61-68, 1994.

BAÑUELOS, G.; TERRY, N.B.; LEDUC, D.L.; PILLON-SMITS, E.A.H.; MACKEY, B. Field trial of transgenic Indian mustard plants shows enhanced phytoremediation of selenium-contaminated sediment. Environmental Science and Technology, v.39, p.1771$1777,2005$.

BECHER, M.; TALKE, I.N.; KRALL, L.; KRÄMER, U. Cross-species microarray transcript profiling reveals high constitutive expression of metal homeostasis genes in shoots of the zinc hyperaccumulator Arabidopsis halleri. Plant Journal, v.37, p.251-268, 2004.

BERNAL, M.P.; MCGRATH, S.P.; MILLER, A.J.; BAKER, A.J.M. Comparison of the chemical changes in the rhizosphere of the nickel hyperaccumulator Alyssum murale with the non-accumulator Raphanus sativus. Plant and Soil, v.164, p.251-259, 1994.

BLAYLOCK, M.J. Field demonstrations of phytoremediation of leadcontaminated soils. In: TERRY, N.; BAÑUELOS, G. (Ed.). Phytoremediation of contaminated soil and water. Boca Raton: Lewis Publishers, 2000. p.1-12.
BLAYLOCK, M.J.; DUSHENKOV, S.; ZAKHAROVA, O.; GUSSMAN, C.; KAPULNIK, Y.; ENSLEY, B.D.; SALT, D.E.; RASKIN, I. Enhanced accumulation of $\mathrm{Pb}$ in Indian mustard by soil-applied chelating agents. Environmental Science and Technology, v.31, p. 860-865, 1997.

BOUWMAN, L.A.; BLOEM, J.; RÖMKENS, P.F.A.M.; JAPENGA, J. EDGA amendment of slightly heavy metal loaded soil affects heavy metal solubility, crop growth and microbivorous nematodes but not bacteria and herbivorous nematodes. Soil Biology \& Biochemistry, v.37, p.271-278, 2005.

BROWN, S.L.; CHANEY, R.L.; ANGLE, J.S.; BAKER, A.J.M. Phytoremediation potential of Thlaspi caerulescens and bladder campion for zinc-contaminated and cadmium-contaminated soil. Journal of Environmental Quality, v.23, p.1151-1157, 1994.

CHANEY, R.L. Plant uptake of inorganic waste constituents. In: PARR, J.F.; MARSCH, P.B.; KLA, J.S. (Ed.). Land treatment of inorganic wastes. Park Ridge: Noyes Data, 1983. p.50-76.

CHANEY, R.L.; MALIK, M.; LI, Y.M.; BROWN, S.L.; BREWER, E.P.; ANGLE, J.S.; BAKER, A.J.M. Phytoremediation of soil metals. Current Opinion in Biotechnology, v.8, p.279-284, 1997.

CHEN, Y.; LI, X.D.; SHEN, Z.G. Leaching and uptake of heavy metals by ten different species of plants during an EDTA-assisted phytoextraction process. Chemosphere, v.57, p.187-196, 2004.

CLEMENS, S.; PALMGREN, M.G.; KRÄMER, U. A long way ahead: understanding and engineering plant metal accumulation. Trends in Plant Science, v.7, p.309-315, 2002.

COBBETT, C.S. Phytochelatins and their roles in heavy metal detoxification. Plant Physiology, v.123, p.825-832, 2000.

COBBETT, C.; GOLDSBROUGH, P. Phytochelatins and metallothioneins: roles in heavy metal detoxification and homeostasis. Annual Review of Plant Biology, v.53, p.159-182, 2002.

COLLINS, R.N.; ONISKO, B.C.; MCLAUGHLIN, M.J.; MERRINGTON, G. Determination of metal-EDTA complexes in soil solution and plant xylem by ion chromatography-electrospray mass spectrometry. Environmental Science and Technology, v.35, p.2589-2593, 2001.

CUNNINGHAM, S.D.; OW, D.W. Promises and prospects of phytoremediation. Plant Physiology, v.110, p.715-719, 1996.

CUNNINGHAM, S.D.; BERTI, W.R. Phytoextraction and phytoestabilization: technical, economic, and regulatory considerations of soil-lead issue. In: TERRY, N.; BAÑUELOS, G. (Ed.). Phytoremediation of contaminated soil and water. Boca Raton: Lewis Publishers, 2000. p.359-376.

DHANKHER, O.P.; LI, Y.J.; ROSEN, B.P.; SHI, J.; SALT, D.E.; SENECOFF, J.F.; SASHTI, N.A.; MEAGHER, R.B. Engineering tolerance and hyperaccumulation of arsenic in plants by combining arsenate reductase and $\gamma$-glutamylcysteine synthetase expression. Nature Biotechnology, v.20, p.1140-1145, 2002.

EBBS, S.D.; KOCHIAN, L.V. Toxicity of zinc and copper to Brassica species: implications for phytoremediation. Journal of Environmental Quality, v.26, p.776-781, 1997.

EBBS, S.D.; KOCHIAN, L.V. Phytoextraction of zinc by oat (Avena sativa), barley (Hordeum vulgare), and Indian mustard (Brassica juncea). Environmental Science and Technology, v.32, p.802-806, 1998.

ENSLEY, B.D. Rationale for use of phytoremediation. In: RASKIN, I.; ENSLEY, B.D. (Ed.). Phytoremediation of toxic metals - Using plants to clean up the environment. New York: John Wiley \& Sons, 2000. p.3-11.

EPSTEIN, A.L.; GUSSMAN, C.D.; BLAYLOCK, M.J.; YERMIYAHU, U.; HUANG, J.W.; KAPULNIK, Y.; ORSER, C.S. EDTA and PbEDTA accumulation in Brassica juncea grown in $\mathrm{Pb}$-amended soil. Plant and Soil, v.208, p.87-94, 1999.

ERNST, W.H.O. Phytoextraction of mine wastes - options and impossibilities. Chemie der Erd, v.65, p.29-42, 2005.

FORSTNER, U. Land contamination by heavy metals: Global scope and magnitude of problem. In: ALLEN, H.E. (Ed.). Metal speciation and contamination of soils. Boca Raton: Lewis Publishers, 1995. p.1-33. 
FREEMAN, J.L.; PERSANS, M.W.; NIEMAN, K.; ALBRECHT, C.; PEER, W.; PICKERING, I.J.; SALT, D.E. Increased glutathione biosynthesis plays a role in nickel tolerance in Thlaspi nickel hyperaccumulators. Plant Cell, v.16, p.2176-2191, 2004.

FREEMAN, J.L.; GARCIA, D.; KIM, D.; HOPF, A.; SALT, D.E. Constitutively elevated salicylic acid signals glutathione-mediated nickel tolerance in Thlaspi nickel hyperaccumulators. Plant Physiology, v.137, p.1082-1091, 2005.

GARBISU, C.; ALKORTA, I. Phytoextraction: a cost-effective plantbased technology for the removal of metals from the environment. Bioresource Technology, v.77, p.229-236, 2001.

GISBERT, C.; ROS, R.; HARO, A.; WALKER, D.J.; BERNAL, M.P.; SERRANO, R.; NAVARRO-AVIÑO, J. A plant genetically modified that accumulates $\mathrm{Pb}$ is especially promising for phytoremediation. Biochemical and Biophysical Research Communications, v.303, p.440-445, 2003.

GLASS, D.J. Economic potential of phytoremediation. In: RASKIN, I.; ENSLEY, B.D. (Ed.). Phytoremediation of toxic metals - Using plants to clean up the environment. New York: John Wiley \& Sons, 2000. p.15-31.

GOLDSBROUGH, P. Metal tolerance in plants: the role of phytochelatins. In: TERRY, N.; BAÑUELOS, G. (Ed.). Phytoremediation of contaminated soil and water. Boca Raton: Lewis Publishers, 2000. p.221-233.

GRILL, E.; WINNACKER, E.L.; ZENK, M.H. Occurrence of heavy metal binding phytochelatins in plants growing in a mining refuse area. Experientia, v.44, p.539-540, 1988.

GROMAN, H.; VODNIK, D.; VELIKONJA-BOLTA, S.; LESTAN, D. Ethylenediaminedissuccinate as a new chelate for environmentally safe phytoextraction. Journal of Environmental Quality, v.32, p.500-506, 2003.

GUPTA, S.K.; HERREN, T.; WENGER, K.; KREBS, R.; HARI, T. In situ gentle remediation measures for heavy metal-polluted soils. In: TERRY, N.; BAÑUElos, G. (Ed.). Phytoremediation of contaminated soil and water. Boca Raton: Lewis Publishers, 2000. p.303-322.

HARTLEY-WHITAKER, J.; AINSWORTH, G.; VOOIJS, R.; TEN BROOKUM, W.; SCHAT, H.; MEHARG, A.A. Phytochelatins are involved in differential arsenate tolerance in Holcus lanatus. Plant Physiology, v.126, p.299-306, 2001.

HIRSCHI, K.D.; KORENKOV, V.D.; WILGANOWSKI, N.L.; WAGNER, G.J. Expression of Arabidopsis CAX2 in tobacco. Altered metal accumulation and increased manganese tolerance. Plant Physiology, v.124, p.125-133, 2000.

HOWDEN, R.; COBBETT, C.S. Cadmium-sensitive mutants of Arabidopsis thaliana. Plant Physiology, v.100, p.100-107, 1992.

HUANG, J.W.W.; CHEN, J.J.; BERTI, W.R.; CUNNINGHAM, S.D. Phytoremediation of lead-contaminated soils: role of synthetic chelates in lead phytoextraction. Environmental Science and Technology, v.31, p.800-805, 1997.

INOUHE, M.; ITO, R.O.S.; SASADA, N.; TOHOYAMA, H.; JOHO, M. Azuki bean cells are hypersensitive to cadmium and do not synthesize phytochelatins. Plant Physiology, v.123, p.1029-1036, 2000.

KASCHL, A.; RÖMHELD, V.; CHEN, Y. Cadmium binding by fractions of dissolved organic matter and humic substances from municipal solid waste compost. Journal of Environmental Quality, v.31, p.1885-1892, 2002.

KERKEB. L.; KRÄMER, U. The role of free histidine in xylem loading of nickel in Alyssum lesbiacum and Brassica juncea. Plant Physiology, v.131, p.716-724, 2003.

KNIGHT, B.; ZHAO, F.J.; MCGRATH, S.P.; SHEN, Z.G. Zinc and cadmium uptake by the hyperaccumulator Thlaspi caerulescens in contaminated soils and its effects on the concentration and chemical speciation of metals in soil solution. Plant and Soil, v.197, p.71-78, 1997.

KOS, B.; LESTAN, D. Chelator induced phytoextraction and in situ soil washing of $\mathrm{Cu}$. Environmental Pollution, v.132, p.333-339, 2004.
KRÄMER, U. Phytoremediation to phytochelatin - plant trace metal homeostasis. New Phytologist, v.158, p.4-6, 2003.

KRÄMER, U.; COTTER-HOWELLS, J.D.; CHARNOCK, J.M.; BAKER, A.J.M.; SMITH, J.A.C. Free histidine as a metal chelator in plants that accumulate nickel. Nature, v.379, p.635-638, 1996.

KRÄMER, U.; SMITH, R.D.; WENZEL, W.W.; RASKIN, I.; SALT, D.E. The role of metal transport and tolerance in nickel hyperaccumulation by Thlaspi goesingense Halacsy. Plant Physiology, v.115, p.1641-1650, 1997.

KRÄMER, U.; PICKERING I.J.; PRINCE R.C.; RASKIN, I.L.; AND SALT, D.E. Subcellular localization and speciation of nickel in hyperaccumulator and non-accumulator Thlaspi species. Plant Physiology, v.122, p.1343-1353, 2000.

KRISHNAMURTI, G.S.R.; CIESLINSKI, G.; HUANG, P.M.; VAN PEES, K.C.J. Kinetics of cadmium release from soils as influenced by organic acids: implication in cadmium availability. Journal of Environmental Quality, v.26, p.271-277, 1997.

KUMAR, P.B.A.N.; DUSHENKOV, V.; MOTTO, H.; RASKIN, I. Phytoextraction: the use of plants to remove heavy metals from soils. Environmental Science and Technology, v.29, p.1232-1238, 1995.

KÜPPER, H.; ZHAO, F.J.; MCGRATH, S.P. Cellular compartmentation of zinc in leaves of the hyperaccumulator Thlaspi caerulescens. Plant Physiology, v.119, p.305-311, 1999.

KÜPPER H.; LOMBI E.; ZHAO F.J.; MCGRATH S.P. Cellular compartmentation of cadmium and zinc in relation to other elements in the hyperaccumulator Arabidopsis halleri. Planta, v.212, p.7584, 2000.

LASAT, M.M. Phytoextraction of toxic metals: A review of biological mechanisms. Journal of Environmental Quality, v.31, p.109-120, 2002.

LASAT, M.M.; KOCHIAN, L.V. Physiology of Zn hyperaccumulation in Thlaspi caerulescens. In: TERRY, N.; BAÑUELOS, G. (Ed.). Phytoremediation of contaminated soil and water. Boca Raton: Lewis Publishers, 2000. p.159-169.

LI, H.; WANG, Q.; CUI, Y.; DONG, Y.; CHRISTIE, P. Slow release chelate enhancement of lead phytoextraction by corn (Zea mays L.) from contaminated soil - a preliminary study. Science of the Total Environment, v.339, p.179-187, 2005.

LIN, Q.; CHEN, Y.X.; CHEN, H.M.; YU, Y.L.; LUO, Y.M.; WONG, M.H. Chemical behavior of $\mathrm{Cd}$ in rice rhizosphere. Chemosphere, v. 50, p.755-761, 2003.

LOMBI, E.; ZHAO, F.J.; DUNHAM, S.J.; MCGRATH, S.P. Phytoremediation of heavy-metal contaminated soils: natural hyperaccumulation versus chemically enhanced phytoextraction. Journal of Environmental Quality, v.30, p.1919-1926, 2001.

MA, J.F. Role of organic acids in detoxification of aluminum in higher plants. Plant Cell Physiology, v.41, p.383-390, 2000.

MA, L.Q.; KOMAR, K.M.; TU, C.; ZHANG, W.H.; CAI, Y.; KENNELLEY, E.D. A fern that hyperaccumulates arsenic. Nature, v.409, p.579, 2001.

MACNAIR, M.R.; TILSTONE, G.H.; SUSANNE, E.S. The genetics of metal tolerance and accumulation in higher plants. In: TERRY, N.; BAÑUELOS, G. (Ed.). Phytoremediation of contaminated soil and water. Boca Raton: Lewis Publishers, 2000. p.235-250.

MADRID, F.; LIPHADZI, M.S.; KIRKHAM, M.B. Heavy metal displacement in chelate-irrigated soil during phytoremediation. Journal of Hydrology, v.272, p.107-119, 2003.

MANN, S.S.; RITCHIE, G.S.P. The influence of $\mathrm{pH}$ on the forms of cadmium in four west Australian soils. Australian Journal of Soil Research, v.31, p.255-270, 1993.

MARCHIOL, L.; ASSOLARI, S.; SACCO, P.; ZERBI, G. Phytoextraction of heavy metals by canola (Brassica napus) and radish (Raphanus sativus) grown on multicontaminated soil. Environmental Pollution, v.132, p.21-27, 2004.

MARSCHNER, H. Mineral nutrition of higher plants. 2.ed. San Diego: Academic Press, 1995. 889p.

McGRATH, S.P.; SHEN, Z.G.; ZHAO, F.J. Heavy metal uptake and chemical changes in the rhizosphere of Thlaspi caerulescens and Thlaspi ocholeucum grown in contaminated soils. Plant and Soil, v.188, p.153-159, 1997. 
McGRATH, S.P.; ZHAO, F.J.; LOMBI, E. Plant and rhizosphere processes involved in phytoremediation of metal-contaminated soils. Plant and Soil, v.232, p.207-214, 2001.

McGRATH, S.P.; ZHAO, F.J.; LOMBI, E. Phytoremediation of metals, metalloids, and radionuclides. Advances in Agronomy, v.75, p.156, 2002.

MEERS, E.; HOPGOOD, M.; LESAGE, E.; TACK, F.M.G.; VERLOO, M.G. Enhanced phytoextraction: in search for EDTA alternatives. International Journal of Phytoremediation, v.6, p.95-109, 2004.

MENCH, M.; MARTIN, E. Mobilization of cadmium and other metals from two soils by root exudates of Zea mays L., Nicotiana tabacum L. and Nicotiana rustica L. Plant and Soil, v.132, p.187-196, 1991.

NASCIMENTO, C.W.A.; AMARASIRIWARDENA, D.; XING, B. Comparison of natural organic acids and synthetics chelates at enhancing phytoextraction of metals from a multi-metal contaminated soil. Environmental Pollution, v.140, p.114-123, 2006.

NEUMANN D.; ZUR NIEDEN, U. Silicon and heavy metal tolerance of higher plants. Phytochemistry, v.56, p.685-692, 2001.

PERSANS, M.W.; YAN, X.G.; PATNOE, J.M.M.L.; KRÄMER, U.; SALT, D.E. Molecular dissection of the role of histidine in nickel hyperaccumulation in Thlaspi goesingense (Hálácsy). Plant Physiology, v.121, p.1117-1126, 1999.

PILON-SMITS, E. Phytoremediation. Annual Review of Plant Biology, v.56, p.15-39, 2005.

PIÑEROS, M.A.; MAGALHÃES, J.V.; ALVES, V.M.C.; KOCHIAN, L.V. The physiology and biophysics of an aluminum tolerance mechanism based on root citrate exudation in maize. Plant Physiology, v.129, p.1194-1206, 2002.

QUARTACCI, M.F.; BAKER, A.J.M.; NAVARI-IZZO, F. Nitrilotriacetate- and citric acid-assisted phytoextraction of cadmium by Indian mustard (Brassica juncea (L.) Czernj, Brassicaceae). Chemosphere, v.59, p.1249-1255, 2005.

RAUSER, W.E. Phytochelatins and related peptides - structure, biosynthesis and function. Plant Physiology, v.109, p.1141-1149, 1995.

REEVES, R.D.; BROOKS, R.R. European species of Thlaspi L. (Cruciferae) as indicators of nickel and zinc. Journal of Geochemical Exploration, v.18, p.275-283, 1983.

REEVES, R.D.; BAKER, A.J.M. Metal-accumulating plants. In: RASKIN, I.; ENSLEY, B.D. (Ed.). Phytoremediation of toxic metals - Using plants to clean up the environment. New York: John Wiley \& Sons, 2000. p.193-229.

RENELLA, G.; LANDI, L.; NANNIPIERI, P. Degradation of low molecular weight organic acids complexed with heavy metals in soil. Geoderma, v.122, p.311-315, 2004.

RÖMKENS, P.; BOUWMAN, L.; JAPENGA, J.; DRAAISMA, C. Potentials and drawbacks of chelate-enhanced phytoremediation of soils. Environmental Pollution, v.116, p.109-121, 2002.

ROOSENS, N.; VERBRUGGEN, N.; MEERTS, P.; XIMÉNEZENBÚM, P.; SMITH, J.A.C. Natural variation in cadmium tolerance and its relationship to metal hyperaccumulation for seven populations of Thlaspi caerulescens from Western Europe. Plant, Cell and Environment, v.26, p.1657-1672, 2003.

RYAN, P.R.; DELHAIZE, E.; JONES, D.L. Function and mechanism of organic anion exudation from plant roots. Annual Review of Plant Physiology and Plant Molecular Biology, v.5, p.527-560, 2001.

SALT, D.E.; PRINCE, R.C.; PICKERING, I.J.; RASKIN, I. Mechanisms of cadmium mobility and accumulation in Indian mustard. Plant Physiology, v.109, p.1427-1433, 1995.

SALT, D.E.; SMITH, R.D.; RASKIN, I. Phytoremediation, Annual Review Plant Physiology Plant Molecular Biology, v.49, p.643$668,1998$.

SALT, D.E.; KRÄMER, U.; SMITH, R.D.; RASKIN, I. The role of root exudates in nickel hyperaccumulation and tolerance in accumulator and nonaccumulator species of Thlaspi. In: TERRY, N.; BAÑUELOS, G. (Ed.). Phytoremediation of contaminated soil and water. Boca Raton: Lewis Publishers, 2000. p.189-200.
SARRET, G.; VANGRSONSVELD, J.; MANCEAU, A.; MUSSO, M.; D'HAEN, J.; MENTHONNEX, J.J.; HAZEMAN, J.L. Accumulation forms of $\mathrm{Zn}$ and $\mathrm{Pb}$ in Phaseolus vulgaris in the presence and absence of EDTA. Environmental Science and Technology, v.35, p.28542859,2001

SARRET, G.; SAUMITOU-LAPRADE, P.; BERT, V.; PROUX, O.; HAZEMANN, J.L.; TRAVERSE, A.S.; MARCUS, M.A.; MANCEAU, A. Forms of zinc accumulated in the hyperaccumulator Arabidopsis halleri. Plant Physiology, v.130, p.1815-1826, 2002.

SATROUTDINOV, A.D.; DEDYUKHINA, E.G.; CHISTYAKOVA, T.I.; WITSCHEL, M.; MINKEVICH, I.G.; EROSHIN, V.K.; EGLI, T. Degradation of metal-EDTA complexes by resting cells of the bacterial strain DSM 9103. Environmental Science and Technology, v.34, p.1715-1720, 2000.

SCHMÖGER, M.E.V.; OVEN, M.; GRILL, E. Detoxification of arsenic by phytochelatins in plants. Plant Physiology, v.122, p.793-801, 2000.

SHUMAN, L.M. Fractionation method for soil microelements. Soil Science, v.140, p.11-22, 1985.

SUN, B.; ZHAO, F.J.; LOMBI, E.; MCGRATH, S.P. Leaching of heavy metals from contaminated soils using EDTA. Environmental Pollution, v.113, p.111-120, 2001.

TAMURA, H.; HONDA, M.; SATO, T.; KAMACHI, H. Pb hyperaccumulation and tolerance in commom buckwheat (Fagopyrum esculentum Moench). Journal of Plant Research, v.118, p.355-359, 2005.

TOLRA, R.P.; POSCHENRIEDER, C.; BARCELÓ, J. Zinc hyperaccumulation in Thlaspi caerulescens: II. Influence on organic acids. Journal of Plant Nutrition, v.19, p.1541-1550, 1996.

TURGUT, C.; PEPE, M.K.; CUTRIGHT, T.J. The effect of EDTA and citric acid on phytoremediation of $\mathrm{Cd}, \mathrm{Cr}$, and $\mathrm{Ni}$ from soil using Helianthus annuus. Environmental Pollution, v.131, p.147-154, 2004.

VAN HOOF, N.A.L.M.; HASSINEN, V.H.; HAKVOORT, H.W.J.; BALLINTIJN, K.F.; SCHAT, H.; VERKLEIJ, J.A.C.; ERNST, W.H.O.; KARENLAMPI, S.O.; TERVAHAUTA, A.I. Enhanced copper tolerance in Silene vulgaris (Moench) Garcke populations from copper mines is associated with increased transcript levels of a 2b-type metallothionein gene. Plant Physiology, v.126, p.1519-1526, 2001.

VASSIL, A.D.; KAPULNIK, Y.; RASKIN, I.; SALT, D.E. The role of EDTA in lead transport and accumulation by Indian mustard. Plant Physiology, v.117, p.447-453, 1998.

VÁZQUEZ, M.D.; BARCELÓ, J.; POSCHENRIEDER, C.; MADICO, J.; HATTON, P.; BAKER, A.J.M.; COPE, G.H. Localization of zinc and cadmium in Thlaspi caerulescens (Brassicaceae), a metallophyte that can hyperaccumulate both metals. Journal of Plant Physiology, v.140, p.350-355, 1992.

VÁZQUEZ, M.D.; POSCHENRIEDER, C.; BARCELÓ, J.; BAKER, A.J.M.; HATTON, P.; COPE, G.H. Compartmentation of zinc in roots and leaves of the zinc hyperaccumulator Thlaspi caerulescens. Botanica Acta, v.107, p.243-250, 1994.

WAISEL, Y.; ESHEL, A.; KAFKAFI, U. Plant roots: the hidden half. 2.ed. New York: Marcel Dekker, 1996. 1002p.

WALKER, T.S.; BAIS, H.P.; GROTEWOLD, E.; VIVANCO, J.M. Root exudation and rhizosphere biology. Plant Physiology, v.132, p.44$51,2003$.

WELPER, G.; BRUMMER, G.W. Microbial toxicity of $\mathrm{Cd}$ and $\mathrm{Hg}$ in different soil related to total and water-soluble contents. Ecotoxicology and Environmental Safety, v.38, p.200-204, 1997.

WENZEL W.W.; UNTERBRUNNER R.; SOMMER P.; SACCO P. Chelate-assisted phytoextraction using canola (Brassica napus L.) in outdoors pot and lysimeter experiments. Plant and Soil, v.249, p.83-96, 2003.

WHITING, S.N.; DE SOUZA, M.P.; TERRY, N. Rhizosphere bacteria mobilize $\mathrm{Zn}$ for hyperaccumulation by Thlaspi caerulescens. Environmental Science and Technology, v.35, p.3144-3150, 2001.

WU, L.H.; LUO, Y.M.; CHRISTIE, P.; WONG, M.H. Effects of EDTA and low molecular weight organic acids on soil solution properties of a heavy metal polluted soil. Chemosphere, v.50, p.819-822, 2003. 
WU, L.H.; LUO, Y.M.; XING, X.R.; CHRISTIE, P. EDTA-enhanced phytoremediation of heavy metal contaminated soil with Indian mustard and associated potential leaching risk. Agriculture, Ecosystems and Environment, v.102, p.307-318, 2004.

ZENK, M.H. Heavy metal detoxification in higher plants. A review. Gene, v.179, p.21-30, 1996.

ZHAO, F.J.; HAMON, R.E.; McLAUGHLIN, M.J. Root exudates of the hyperaccumulator Thlaspi caerulescens do not enhance metal mobilization. New Phytologist, v.151, p.613-620, 2001.
ZHU, I.L.; PILON-SMITS, E.A.H.; TARUN, A.S.; WEBER, S.U.; JOUANIN, L.; TERRY, N. Cadmium tolerance and accumulation in Indian mustard is enhanced by overexpressing $\gamma$-glutamylcysteine synthetase. Plant Physiology, 121, 1169-1177, 1999.

Received December 19, 2005

Accepted May 16, 2006 